УДК 340.12:241.41

DOI 10.35423/2078-8142.2020.1.12

M. B. Hecnpaвa,

доктор філософських наук, дочент, професор кафедри міжнародних відносин та туризму, Дніпропетровський державний університет внутрішніх справ

м. Дніпро, Україна e-mail:n.nesprava@gmail.com ORCID: https://orcid.org/0000-0003-0415-1837

\title{
ПРОБЛЕМА НАСИЛЬСТВА У ХРИСТИЯНСЬКІЙ ОНТОЛОГО-АКСІОЛОГІЧНІЙ ПАРАДИГМІ ДОБРА І ЗЛА
}

У статті розкриті екзистенціальні причини насильства та визначені його сутнісні характеристики з позиџій християнської онтолого-аксіологічної парадигми. Проаналізовані основні біблійні постулати щодо природи та сутності добра $і$ зла. Представлено тлумачення добра як свободи, обмеженої лише Божими заповідями. Показано, що онтологічною передумовою виникнення проблеми добра і зла є діалектичне співвідношення двох чинників: Божого закону і людської свободи. Окреслені ключові позичії взаємозв'язку між злом, гріхом та насильством. Визначено, щзо гріх - це зловживання свободою, яке виражається у порушенні людиною Божих заповідей, тобто ие свідомий вибір на користь зла. Встановлено, що першопричиною насильства було гріхопадіння, а існування насильства у сучасному світі зумовлено зневірою. Виявлено відмінність у трактуванні та оціненні насильства. Показано, щяо у Старому заповіті насильство розглядається не лише як зло, а й як необхідне покарання за гріх або справедлива помста. Напроти, християнська онтолого-аксіологічна парадигма, визнаючи у певних випадках припустимість насильства для боротьби з конкретними проявами гріховного зла, постулює ненасильство як моральний обов'язок. Дана позииія базується на євангельських заповідях, за якими добро означає любов, милосердя і прощення. Із иієї позииіі проведено порівняння кониепиії непротивлення злу насильством та 
концепиї допустимості силового спротиву. Розкрито значення умовиводу християнських філософів, щзо лише перемога над злом у своій душі відкриває людині можливість справедливого застосування сили. 3'ясовано, щчо проблема насильства набуває особливої складності внаслідок суб' єктивності оиінки добра $і$ зла як соиіальних явищ. Аргументована наявність сутнісної диферениіації між гріховним і негріховним насильством. Запропоновані критерії, за котрими насильство слід класифікувати як негріховне. Доведено, щзо насильство, тенеза якого онтологічно пов'язана зі злом, втім, може бути визначене як негріховне та мати певне виправдання з позицій християнської аксіологї якщо воно: по-перше, має характер попередження або протидії, а не помсти; по-друге, не принижує гідність людини; по-третє і головне, скероване вищими постулатами любові, а не боротьбою за матеріальні иінності або соцііально-політичні чи релігійні ідеали як такі.

Ключові слова: Божі заповіді, віровчення, свобода, гріх, духовні иінності, любов, милосердя, непротивлення, сила, моральна оиінка, відповідальність.

Насильство супроводжувало людство протягом усієї його історії. Деякі мислителі навіть вважали такі прояви масового насильства як війни та революції двигунами прогресу та історії, а їх припинення називали «кінцем історії». Але розвиток соціальнополітичних процесів протягом перших двох декад XXI ст. засвідчив, що омріяного кінця історії насильства не видно, більше того, загострення боротьби за ресурси, розвиток сучасних військових технологій, розповсюдження зброї масового знищення та сплеск міжнародного тероризму, які часто знаходяться у небезпечному взаємозв'язку, вже загрожують власне існуванню людства і життя взагалі. У глобалізованому світі існуючи міжнародноправові інструменти попередження насильства виявились неефективними, а застосування насильства у внутрішніх конфліктах призводить не лише до колапсу держав і суцільного некерованого хаосу, а й до багатотисячних жертв. На жаль, цей трагічний досвід не оминув і Україну. Моніторингова місія ООН з прав людини заявила, що в результаті збройного конфлікту на Сході України з квітня 2014 року до кінця 2018 року загинули від 12800 до 13 тисяч осіб [3]. Крім того, метастази насильства глибоко проникають у внут- 
рішні тканини українського суспільства, про що свідчить статистика злочинності. На тлі загального зниження кількості правопорушень у країні зростає кількість навмисних вбивств та насильницьких злочинів, скоєних з особливою жорстокістю [2]. Жахливими $€$ й наслідки так званого побутового насильства. Щороку в Україні від рук партнерів гинуть 600 жінок, а 1,1 мільйон українок стикаються 3 фізичною та сексуальною агресією в сім’ї [18].

Отже, перед суспільством постала нагальна потреба у перегляді існуючого ставлення до насильства, яке нині переважно грунтується на раціоналістичній парадигмі. Очевидно, що ця парадигма призвела до розмивання в індивідуальній та суспільній свідомості фундаментальних критеріїв добра і зла, тому дороговказ для виходу з кризи слід шукати у духовних джерелах. Таким чином, аналіз базових положень християнської онтолого-аксіологічної парадигми та відповідним чином осучаснене застосування притаманних їй критеріїв добра і зла для виявлення причин та оцінювання властивих XXI століттю проявів насильства на усіх його рівнях $є$ актуальним завданням суспільствознавства.

Зі стародавніх часів мислителі намагалися зрозуміти сутнісні причини насильства, розкрити його роль у бутті окремої людини та соціуму та знайти критерії для оцінювання насильницьких діянь, використовуючи поняття добра і зла. Перші наративи і настанови 3 цього приводу знаходимо ще у Біблії. Глибокі роздуми на цю тему містяться у філософській спадщині Конфуція, Сократа, Платона, Аристотеля. Але докорінно новий підхід до означеної проблематики був започаткований у межах християнського віровчення. Важливе значення 3 точки зору предмета нашого дослідження мають думки, висловлені видатними християнськими теологами, такими як Аврелій Августин і Фома Аквінський. Різноманітні концепції насильства були розроблені філософами епохи Просвітництва i Нового часу Н. Макіавеллі, Г. Гроцієм, Б. Спінозою, І. Бентамом, Т. Гоббсом, Дж. Локком, Ж.-Ж. Руссо, Вольтером, Ш.-Л. Монтеск'є, Дж. Міллем та ін. Підкреслимо, що всі вони мали різні думки щодо доцільності використання Свангельських заповідей для оцінювання насильства. Тому у цьому контексті особливу увагу привертають умовиводи українських християнських філософів Г. Сковороди і П. Юркевича, які заснували школу каріоцентризму, а та154

H.Skovoroda Institute of Philosophy of the NAS of Ukraine 
кож представників російської філософії «срібного віку», зокрема, I. Ільїна, а також вражаючі за своєю прозорливістю висновки стосовно причин насильства та відповідальності за нього, які містяться у творах відданого християнина Ф. М. Достоєвського. При цьому необхідно підкреслити, що, не зважаючи на строкатість палітри, якою вимальовувалась ця категорія у творчості різних авторів, іii онтолого-аксіологічним підгрунтям завжди була філософська парадигма добра і зла. Фундаментальні основи класичних філософських течій, які, не зважаючи на критику, і досі здійснюють потужний вплив на розвиток цієї парадигми, заклали І. Кант, Г.В.Ф. Гегель, К. Маркс, С. К'єркегор, Ф. Ніцше. Вододіл між ними проходить по лінії основного питання філософії. У цій статті ми перш за усе спираємось на думки тих мислителів, які обстоювали пріоритетність духовних начал у бутті соціуму та у формуванні системи його цінностей.

Відзначимо, що у сучасній філософський думці грунтовні доробки у напрямку визначення різних аспектів співвідношення добра і зла з насильством представлені у працях таких вчених, як Ф. Алкінсон, Р. Г. Апресян, О. В. Артем’єва, А. Бад’ю, Г. Барзілаї, Р. Баумайстер, В. Беджамін, І. Гальтунг, Я. І. Гилинський, А. А. Гусейнов, Дж. Девей, О. А. Дмитрієв, С. Жижек, І. В. Залисін, Ф. Е. Кац, П. С. Матвєєв, В. Мандрагель, Д. А. Метилко, С. Мінц, А. П. Назарєтян, В. О. Остроухов, Д. Річес, Я. Рєємтс, П. Саух, Дж. Стауфер. Вельми цікавими для нашого дослідження $є$ висновки щодо визначальних рис християнської онтології добра і зла та релігійного оцінювання насильства, які містяться у працях французького релігієзнавця Р. Жерара, його американських колег Л. Гібсона, Е. Кремера, Ш. Метьюза та української дослідниці Г. І. Савонової.

Утім, не зважаючи на широку наукову базу, котра висвітлює кореляції між категоріями добра і зла та насильством, дискусії щодо причин насильства та критеріїв його морального оцінювання не вщухають. При цьому розгляд цієї проблематики крізь призму християнського віровчення здебільшого концентрується лише на ключових біблійних постулатах або умовиводах окремих авторитетних теологів. Отже, питання щодо комплексного аналізу основних підходів християнської онтолого-аксіологічної парадигми добра i 
зла до визначення сутнісних причин та оцінювання насильства залишається відкритим.

Стаття має за мету показати онтологічні джерела насильства та охарактеризувати аксіологічні критерії оцінювання конкретних насильницьких дій, як вони трактуються в межах християнської парадигми добра і зла.

Насильство як спосіб боротьби за існування можна вважати іманентною властивістю живої природи. За Дарвіном, принцип «виживає найсильнішій» постає як стрижень закону природного відбору, який апологети секуляризму закладають у фундамент природного права. Але це твердження є вірним тільки якщо природне право ототожнюється із «законом джунглів». Утім, на переконання релігійних філософів, людина як істота, створена за образом і подобою Бога, відрізняється від інших природних істот тим, що не обмежена законами природи, iї дії не зумовлені тільки біологічними інстинктами виживання. Людина прагне пізнати Боже право, вона здатна до трансцендентної оцінки як себе, так і навколишнього світу та володіє унікальною для всіх природних суб'єктів можливістю свободи вибору. Ці визначальні ознаки людського буття породили базові аксіологічні категорії добра і зла, які використовуються для оцінювання соціальних явищ та процесів, зокрема i таких, як насильство, у відмінній від законів природи системі координат.

Дилема добра і зла є найскладнішим і найдавнішим світоглядним питанням, що постало перед людиною. За Біблійним оповіданням, саме скоштувавши плід дерева пізнання добра і зла, Адам наклав тягар первородного гріха на всіх своїх нащадків. За цей гріх Бог вигнав Адама і Єву з раю та встановив їм покарання за провину. Таким чином було застосовано і перший акт насильства. Це оповідання демонструє діалектичний зв'язок між злом, гріхом та насильством. Воно ж відкриває і деякі ключові позиції цього взаємозв'язку. Зло як зовнішній чинник спокушає людину, але гріх вона вчиняє внаслідок власного вільного вибору. Можливість такого вільного вибору - свобода $є$ одним з найвищих дарів Бога людині і як конкретному носію образу особистого Бога, і як члену суспільства особистостей в єдності людського роду. Можна погодитись із твердженням знаного данського християнського філософа Серена 156

H.Skovoroda Institute of Philosophy of the NAS of Ukraine 
К'єркегора, що «тільки для свободи й у свободі існує різниця між добром і злом» [9]. Але при цьому ми не згодні з тим спрощеним висновком, що «свобода-дана» є добром, а «несвобода-обмежена» - злом. Слід звернути увагу на слова святителя Григорія Богослова: «Той, Хто створив на початку людину, зробив іiі вільною і самовладною, обмеживши іiі одним лише законом заповіді» [4]. Отже, добром є свобода, обмежена Божими заповідями. Коли людина перетинає цю межу, піддавшись диявольській спокуті та переповнюючись власною гординею, вона покидає світ Божого добра та поринає у темряву зла. І у цьому сенсі можна сказати, що гріх - це зловживання свободою, яке виражається у порушенні людиною Божих заповідей. Таким чином, свобода, коли вона помилково розуміється як безмежність особистої волі, призводить до виходу 3 підпорядкування Богу та потурання злу, що спричиняє гріхопадіння, котре й зумовлює існування насильства у світі, а зло із зовнішнього фактора, що представлявся людям в образі диявола, стає невід'ємною частиною внутрішнього світу самої людини. I ось тут постають найважливіші онтолого-аксіологічні питання: чи можливо подолати зло, яке оселилося у людському серці внаслідок гріхопадіння? А якщо можливо, то у який спосіб?

Проаналізувавши викладені у Біблії положення щодо співвідношення добра і зла, гріха і насильства, ми можемо вирізнити два діалектично пов'язані підходи: старозавітний та євангельський. У Старому Завіті гріх розглядається як злочин, Бог - як суддя, причому дуже строгий, а людина - як злочинець, який обов'язково повинен понести суворе покарання. На цьому підході грунтується і принцип таліону. Одне з найдавніших відомих його формулювань - вислів «око за око, зуб за зуб» - $\epsilon$ цитатою з Книги Виходу (21: 23-27), повторена також у Левіта (24:20), яка не лише виправдовує насильство, а й фактично зобов'язує до нього. Саме цей принцип лежить в основі традиції кровної помсти. Однак у помсти немає міри, одна помста породжує іншу, інша - третю, що може призвести до повного винищення роду. Тобто кінець кінцем зло одержує гору і запановує смерть.

Але у Христі, який «смертію смерть поправ», людство знайшло шанс на спасіння. Милосердя, що його сповідує християнство, співвідноситься з принципом рівної відплати, за діалектичним за- 
коном «заперечення заперечення». У Нагірній проповіді Христос проголосив: «Ви чули, що нашим батькам було сказано: «Око за око і зуб за зуб». А я кажу вам, що не чиніть опір тому, хто ображає вас. Навпаки, якщо хто-небудь б’є тебе по правій щоці, дозволь йому вдарити тебе і по лівій!» (Мтф.5: 38-41). У Свангелії ми знаходимо не лише зрозумілу заповідь: «Полюби ближнього твого, як самого себе» (Мтф. 22:39), а й більш складну когнітивну модель: «Любіть ворогів ваших, благословляйте тих, хто проклинає вас, хто ненавидить вас, і моліться за тих, хто кривдить вас і жене вас, щоб вам бути синами Батька вашого небесного» (Мтф. 5: 4346). Американські релігієзнавці Лі Гібсон і Шеллі Метьюз звертають увагу на те, що деякі вчені, такі як Рене Жирар, підносять Новий Завіт як такий, що містить антидот для насильства Старого Завіту. Вони стверджують, що такий умовивід грунтується на поглядах єресіарха Маркіона Сінопи (бл. 85-160 рр.), який вказав на відмінність між Богом Старого Завіту, відповідальним за насильство, і Богом милосердя, знайденим в Новому Завіті [22, с. 1-3]. Таким чином, можемо констатувати, що у християнстві добро означає любов, милосердя і прощення. Ці критерії $є$ загальновизнаними маркерами християнського етосу.

Утім, окремі положення християнської онтологоаксіологічної парадигми добра і зла трактується по-різному. Зокрема, в ній дискутується проблема гріховного та негріховного насильства. У загальній філософській полеміці можна вирізнити принаймні дві концепції. Перша - розглядає непротивлення злу як абсолютний закон, а насильство вважає універсальним критерієм гріха, що проявляється у його антагонізмі до християнських постулатів любові. Цю концепцію найбільш послідовно обстоював Лев Толстой, який вважав, що боротися зі злом людина має у собі. Із погляду оцінення ефективності практичного застосування цієї концепції слід звернутися до політичного досвіду Махатми Ганді, який прийняв концепцію ненасильства, котру він знайшов у Новому Завіті, зокрема у Нагірній проповіді, та звитяжно використав у своїй стратегії соціальної і політичної боротьби [23, с. 54-55].

Друга концепція вказує на реляційний характер заповіді непротивлення злу насиллям та розробляє етичні принципи допустимості силового спротиву. Такий погляд представлений у працях 158

H.Skovoroda Institute of Philosophy of the NAS of Ukraine 
Фоми Аквінського, Гуго Гроція, Івана Ільїна та інших мислителів, які вважали, що християнські ідеали вимагають боротьби не лише iз внутрішніми, а й із зовнішніми проявами зла. «Один з найважливіших уроків, який слід витягти з міркувань про заповіді непротивлення злу, полягає в усвідомленні того, що боротьба зі злом як таким без боротьби з реальними проявами зла навряд чи можлива, зазначає сучасний російський філософ Ольга Артем'єва. - Міркування про непротивлення у відриві від спроби відповісти на питання про способи і форми протистояння реальним проявам зла нівелює моральну цінність непротивлення» [1, с. 94].

Означені екзистенціальні відмінності у розумінні сутності насильства, мети та меж його застосування зумовлені тим, що порівняно 3 попередньою традицією християнське богослов'я використовує зовсім інші категорії для тлумачення гріха. Для нього гріх - це смертельне захворювання, людина - важко хворий паці$\epsilon н т$, а Бог - люблячий лікар. Шостий Вселенський Православний Собор прямо визначив гріх як хворобу душі, а конфлікти, чвари, злочини і війни 3 їх трагічними наслідками є лише зовнішніми симптомами цієї хвороби. Отже, як наголошують предстоятелі Церкви, для попередження злочинів, припинення війн і подолання тероризму треба усунути не лише зовнішні симптоми цієї хвороби, а й саму хворобу - гріх [14]. Як хірург застосовує скальпель для видалення злоякісної пухлини та може спричиняти біль пацієнту, так і лікування гріха може вимагати застосування сили та спричиняти страждання. I саме у цьому сенсі слід розуміти неоднозначно трактований вислів Христа: «... не мир прийшов Я принести, але меч» (Мтф. 10:34). Керуючись Свангельським словом, ми 3 упевненістю можемо сказати, що довічне існування зла не означає, що людина не має боротися 3 ним. Більше того, саме у цьому і полягає iii божественне призначення.

I хоча, з точки зору християнської аксіології, будь-яке насильство у моральній оцінці є злом, але не будь-яке насильство є гріховним злом. Видатний православний філософ І. О. Ільїн, свідомо уникаючи терміна «насильство», який, на його думку, упереджено несе негативну окраску, стверджував, що всякий гріх $є$ різновидом неправедності, але далеко не всяка неправедність є гріхом» [7, с. 192]. Жодна людина не може уникнути зла, але людина може 
і повинна уникати гріха, - звідси і особлива відповідальність людини за вчинений гріх. Людина несе моральну провину за будь-яке насильство, і особливу, а в належних випадках і правову, відповідальність за гріховне насильство. Людина не повинна здійснювати гріховного насильства, бо для нього немає морального виправдання, але людина може, а іноді і повинна чинити насильство, яке не $\epsilon$ гріховним.

В «Основах соціальної концепції» Руської Православної Церкви відзначено: «Моральний християнський закон засуджує не боротьбу зі злом, не застосування сили по відношенню до його носія і навіть не позбавлення життя, як крайню міру, але злість серця людського, бажання приниження і смерті кому б то не було. Лише перемога над злом у своїй душі відкриває людині можливість справедливого застосування сили. Такий погляд, стверджуючи у відносинах між людьми верховенство любові, рішуче відкидає ідею непротивлення злу силою» [16]. Своєю чергою, наголошуючи на наявності у людини вищих духовних якостей як необхідної умови допустимості насильства, I. О. Ільїн писав: «Той, хто чинить опір злодіям силою і мечем, той повинен бути чистіше і вище своєї боротьби; інакше не він поведе іiі і не він завершить іiі перемогою, а вона захопить його, спотворить його обличчя і викине його, зломленого, приниженого і порочного. Володіти силою і мечем може лише той, хто володіє собою, тобто своїми пристрастями і своїм баченням» [7, с. 217].

Отже, виходячи з християнських постулатів, ми можемо констатувати, що попередити зло за допомогою насильства означає попередити гріх, проте мститися насильством за зло - здійснювати гріх. Крім того, насильство не є гріхом, якщо воно не принижує гідності людини. У цьому зв'язку можна послатися на досвід видатного українського педагога Антона Макаренко, який стверджував, що дитину вдарити можна, але не можна принизити [12, с. 544].

Крім того, правомірність застосування певного насильства, що завжди має супроводжуватися ситуативним аналізом, випливає із сутності самого добра і зла та діалектики їх співвідношення. При цьому необхідно наголосити, що вибір способу насильства має бути скоригованим за принципом співмірності дії у відповідь та визначатися не стільки ії властивостями як «зовнішнього» засобу за160

H.Skovoroda Institute of Philosophy of the NAS of Ukraine 
побігання або припинення зла, а передусім як «внутрішнього» засобу виховання.

Відзначимо, що у соціально-філософський літературі та нормативно-правових документах існує багато варіантів дефініцій насильства. Одним 3 найбільш універсальних вважається визначення, прийняте ООН, згідно з яким насильство - це навмисне застосування фізичної сили або влади, дійсне або у вигляді загрози, спрямоване проти себе, проти іншої особи, групи осіб або суспільства, результатом якого $є$ (або є висока ступінь ймовірності цього) тілесні ушкодження, смерть, психологічна травма, відхилення в розвитку або різного роду збитки $[15$, с. 5]. Важливо звернути увагу на окремі аспекти цього визначення. Зокрема, вислів «використання фізичної сили або влади» слід розуміти не лише як вбивство та будь-який замах на життя або здоров'я, у тому числі власне, та інші види жорстокого поводження (фізичного, сексуального чи психологічного), а й як відсутність турботи, ненадання допомоги або нехтування, що теж вважаються насильницькими актами. $€$ й інші аспекти, включені в дане визначення насильства, хоча вони і не виражені прямо. Наприклад, неважливо, чи є акти насильства публічними або прихованими від громадськості. Досить складним аспектом у запропонованому визначенні поняття «насильство» $є$ його навмисність. Тут можна зазначити два важливих моменти. Поперше, намір застосувати силу не обов'язково означає, що $є$ намір завдати шкоди. Людина може навмисно зробити якийсь акт, котрий відповідно до об'єктивних стандартів буде вважатися небезпечним і таким, що завдає шкоди здоров’ю, хоча ця людина не вважає його таким. Друге питання, пов'язане з навмисністю, полягає в розрізненні наміру заподіяти тілесне ушкодження 3 наміром «застосувати насильство». Кожен 3 цих аспектів $€$ важливим для розуміння сутнісних причин насильства.

На екзистенціальні причини насильства вказував ще святий апостол Яків, коли наголошував: «Звідки війни та чвари між вами? Чи не звідси, від ваших пожадливостей, що воюють у членах ваших?» (Як. 4:1). Глибокий аналіз соціально-психологічних аспектів насильства міститься у дослідженні авторитетного американського вченого Роя Баумайстера. Він вирізняє чотири причини насильства: садизм, загрозливий егоїзм, інструменталізм та ідеалізм. Са- 
дизм визначається як отримання щирої насолоди від заподіяння шкоди або болю іншому суб'єкту. Але більшість гідних і нормальних людей не дозволять собі визнати, що вони можуть отримати таке задоволення. Тому садизм не можна вважати всеохоплюючою причиною насильства. Вирізняючи загрозливий егоїзм як причину насильства, Р. Баумайстер посилається на результати проведених досліджень, які засвідчують, що нарцисисти є більш агресивними, ніж інші категорії людей. І це, в основному, трапляється, коли вони вважають, що створений ними автообраз знаходиться під загрозою або піддається нападу. При цьому загрозливий егоїзм не обмежується окремими індивідами. Насильницькі, агресивні нації та інші соціальні групи часто демонструють таку саму схему, будучи переконаними, що вони перевершують інших людей, та стверджуючи, що вони не отримують тієї поваги, на яку вони нібито мають право. Інструментальні причини насильства, за Р. Баумайстером, зумовлені тим, що у деяких випадках люди звертаються до насильства, коли вони не можуть отримати те, що вони хочуть, більш прийнятими, законними засобами. Наприклад, терористи частогусто мотивуються тим, що прийняті законні канали соціальних дій, такі, як демократичне голосування чи правова система, не здатні враховувати їхні потреби. На макрорівні війна та тиранічний гніт зазвичай є наслідком дій урядів, які вважають, що вони не можуть досягти своїх цілей менш жорстокими засобами. Зазначимо, що у короткостроковій перспективі насильство справді може бути ефективним. I іноді початкові результати здаються перспективними. Терористи і агресори привертають увагу і руйнують соціальні системи своїх ворогів. Злочинці іноді отримують гроші та інші цінності. Але вчені, які вивчають різні форми інструментального насильства, схиляються до висновку, що будь-яке насильство є неефективним у довгостроковій перспективі. Бо лише невелика купка злочинців стають багатими і потрапляють у життя легкого задоволення, терористи та вбивці не отримують урядування, якого вони хочуть, війни шкодять обом сторонам, а домашні насильники не досягають сімейного щастя, на яке вони сподіваються. Ідеалізм, на думку Р. Баумайстера, є у певному сенсі найбільш тривожною і трагічною причиною насильства, оскільки ідеалісти вважають, що їх благородні цілі виправдовують насильницькі засоби. Найстраш162

H.Skovoroda Institute of Philosophy of the NAS of Ukraine 
ніші злочини ХX століття були здійснені людьми, які вважали, що роблять те, що було необхідно для створення утопічного суспільства, незалежно від того, чи це відображає ліве бачення (як у випадку комуністичних репресій в Китаї та Радянському Союзі), чи праве (як у жахах, скоєних нацистською Німеччиною). Історія також знає чимало випадків вбивств і тортур, вчинених в ім'я релігії, у тому числі й християнства, коли люди вбивали «невірних» та «єретиків», аби служити ідеям «священної війни» чи інквізиції. I хоча іноді ідеалізм виступає прикриттям для основних мотивів, включаючи інструментальні, бо деякі люди використовували релігійні війни або переслідування, щоб збагатити себе, проте нерозумно було б відкинути щирий ідеалізм багатьох винуватців насильства. Наприклад, у такій великій експедиції, як хрестові походи, справді була певна кількість шукачів пригод та тих, хто сподівався на швидке збагачення, але було багато й тих, хто щиро вірив, що вони виконують Божу справу, воюючи з невірними, щоб відновити священну землю, вмираючи за те, що вони вважали істинною вірою [19].

Зрозуміло, що наведені Р. Баумайстером соціальнопсихологічні причини насильства мають перш за усе індивідуальні внутрішні джерела. Водночас, у доповіді Всесвітньої організації охорони здоров'я зазначено, що найостанніші дослідження засвідчують, що хоча біологічні та інші особистісні фактори пояснюють деяку схильність людини до агресії, все ж частіше такі фактори взаємодіють із сімейними, громадськими, культурними та іншими чинниками зовнішнього характеру і таким чином створюють ситуацію, в якій виникає насильство [15]. Схожу позицію обстоює словенський соціальний філософ Славой Жижек. У книзі «Насильство» цей відомий автор проводить відмінність між тим, що він називає суб'єктивним насильством, і об'єктівним насильством. Суб'єктивне насильство відноситься до насильства, яке заподіюється чітко ідентифікованим агентом дії, як у випадку злочинної діяльності або тероризму. Водночас, об’єктивне насильство не має явного винного і часто не береться до уваги на тлі суб’єктивних спалахів насильства. Прикладом об' єктивного насильства Жижек називає глобальну бідність. У ній не може бути звинувачена якась певна організація i, навіть якщо фінансові еліти мали бути визнані 
винними, вони все одно можуть бути реабілітовані шляхом підпорядкування їх системі капіталістичних фінансів. С. Жижек також встановлює, що суб'єктивне насильство, наприклад, злочинна діяльність, може бути наслідком функціонування об'єктивно насильницької економічної системи, яка, своєю чергою, може позбавити цивільних прав групу людей і змусити їх до насильницького опору. Таким чином, він пояснює, як суб'єктивне насильство породжується більш глибокими проблемами, а популярна увага до спалахів насильства з боку певних груп людей тільки відволікає увагу громадськості від кричущих фактів об'єктивного насильства [24].

Погоджуючись 3 тезою, що жити у суспільстві та бути вільним від нього неможливо, ми, втім, вважаємо за необхідне звернути увагу, що з християнської точки зору, відповідальність за гріховне насильство є суто індивідуальною, адже людина має свободу волі. У цьому контексті слід послатися на Федіра Достоєвського, який стверджував, що якщо ми будемо вважати середовище виправданням злочинних вчинків, то це призведе до жахливих наслідків - злочин втратить статус забороненого вчинку, злочин будуть вважати чимось на кшталт «благородного протесту проти середовища». На думку геніального мислителя, «вчення про середовище» $\epsilon$ протилежним до християнських ідей. Він писав, що християнство, хоча і визнає тиск середовища, і проголошує необхідність прояву милосердя до всіх, включаючи й злочинців, водночас також ставить моральним обов'язком для людини боротьбу зі злом. А вчення про визначальний вплив соціального середовища в контексті вчинення злочину є нехристиянським, адже воно намагається звільнити людину від iї морального обов'язку, спростовує наявність у неї свободи волі, особистості і відтак «доводить до мерзеннішого рабства, яке тільки можна уявити» [6, с. 56].

Ми можемо констатувати, що численні експерименти із заснування утопічних спільнот з вірою, що люди будуть жити разом у мирі та гармонії, якщо будуть усунені лише певні гнітючі соціальні умови, зазнали трагічне фіаско. Отже, суто раціоналістичний підхід вводить нас до замкненого кола, що вселяє зневіру у можливість перемоги над злом і подолання насильства. Причина полягає у тому, що, як зауважував Ф. М. Достоєвський, розум не здатен ефективно розмежувати добро та зло і постійно плутає їх, тому в 164

H.Skovoroda Institute of Philosophy of the NAS of Ukraine 
правових питаннях важливим є так званий внутрішній досвід, тобто морально-релігійне чуття, голосом якого в людині є сумління [11, c. 156-157].

Крім того, проведений аналіз засвідчує, що як прийнята $\mathrm{OOH}$ універсальна дефініція насильства, так і наведене визначення його соціально-психологічних причин, залишають відкритими низку питань, котрі стосуються оцінення насильства: відбуваються насильницькі дії у відповідь на чиїсь дії або ж скоєні за власною ініціативою, є вони злочином за законом чи ні i, нарешті, чи завжди насильство є злом? Зрозуміло, що треба розрізняти предметну дію, котра розглядається як насильство, від iї моральної оцінки. Подібна дія може бути співпричетною цінностям як добра, так і зла. Наприклад, насильство над терористами, які утримують заручників, буде насильством по відношенню до терористів і одночасно звільненням заручників. I якщо тут насильство, застосоване до терористів, ще можна оцінити як зло, то звільнення заручників $є$ безперечно добром.

В очах суспільствознавців проблема насильства набуває особливої складності саме внаслідок суб'єктивності оцінення добра і зла як соціальних явищ. Як відзначає Р. Баумайстер, потрібно розрізняти те, що розуміється під добром і злом як природними, соціальними, людськими феноменами, і що розуміється під добром і злом як моральними цінностями. Не все, що сприймається як добро або зло, є добро або зло як моральна цінність. Будь-які конкретні об'єкти або суб'єкти постають носіями цінностей і добра, i зла [21, с. 251].

Суб’єктивний бік є внутрішньою сутністю злочину. Він являє собою психічне ставлення особи до здійснюваного їм суспільно небезпечного діяння, що характеризується виною, мотивом, метою та емоціями. Суб’єктивний бік злочину завжди був однією 3 найбільш дискусійних і важливих філософсько-правових проблем. На нашу думку, найбільш глибоко ця проблема розглянута у романі Ф. М. Достоєвського «Злочин та покарання». Але у цьому контексті ми не можемо погодитися з Р. Лаутом, який зазначає, що «людина, вирішуючи вільно, як їй поводити себе, повністю розрізняє при цьому добро та зло» $[11$, с. 150]. Оскільки більшість лю- 
дей, що їхні дії засуджуються як зло, не оцінюють так само ці власні дії.

Але не лише суб'єкти, а й об'єкти та можливі очевидці злочинів сприйматимуть дії злодіїв не в абсолютно неупередженому, об'єктивному вираженні, а залежно від власної системи цінностей та під впливом емоцій, тобто суб'єктивно. Наявний факт суб'єктивних оцінювальних викривлень вже припускає, що винні у насильницьких діях можуть аргументувати, що вони були неправильно зрозумілі та несправедливо засуджені. Це не означає, що вони є абсолютно безневинними за здійснені акти насильства, але припускає, що їхні дії були не такими жахливими, як стверджують їхні обвинуватці. Тому необхідно визначити зло як в очах об'єкта, котрий може бути жертвою, так і суб'єкта, який, можливо, і не є винуватцем. I це означає, що зло визначається у такий спосіб, який жорстко не прив'язаний до об'єктивної реальності. При цьому в іншій соціальній системі дане конкретне явище може бути оцінено за зовсім іншими моральними критеріями. Як зазначає українська дослідниця Ганна Савонова, «в державних нормативних документах, моральних кодексах, народній етиці діяльність зла визначається по-різному, часто не збігаючись не просто з розумінням зла між окремими суспільними групами, але навіть коли збігаються можуть протистояти розумінню гріха» [17, с. 113]. I хоча відчуття того, що в світі є зло, значно поширене, але попри це суб'єктивні сприйняття мають більше значення для забезпечення визначення зла, ніж будь-яка теорія, в межах якої можуть бути зібрані об'єктивні дані. Очевидно, що різне розуміння понять добра і зла є основною причиною застосування подвійних стандартів в оцінюванні насильницьких дій.

Підкреслимо, що об'єктивне аксіологічне оцінення насильницьких конфліктів, яке було складною справою навіть в умовах традиційного та ізольованого існування різних культур і цивілізацій, виявляється абсолютно неможливим завданням у сучасному, надзвичайно динамічному і глобалізованому світі. Наприклад, 3 кінця 90-х років ХХ ст. Усама бен Ладен почали подавати як уособлення зла, бо він був ідеологом і організатором терористичних атак, які були здійснені його поплічниками 11 вересня 2001 року у США. Утім, наприкінці 80-х він був для американців героєм, оскі166

H.Skovoroda Institute of Philosophy of the NAS of Ukraine 
льки боровся 3 «імперією зла»- Радянським Союзом. І аналогічних прикладів можна навести безліч, у тому числі й в українській істоpiї та сьогоденні. У цьому контексті один з авторитетних фахівців 3 етики Абдусалам Гусейнов відзначає, що «добро і зло, персоніфікація яких тільки і могла б стати моральною санкцією насильства, насправді представлені в кожному суб'єкті, і в такому переплетенні, що одне не існує без іншого. Це виключає можливість морально виправданого і розумно аргументованого насильства, але натомість відкриває широкий простір для його моралізуючого прикриття» [5, c. 22].

Намагання філософів подолати цей суб'єктивізм призвели до розробки категорії абсолютного зла. У релігійній традиції уособленням абсолютного зла виступав диявол. Але саме боротьбою із дияволом католицька і протестантські церкви виправдовували жахливі акти насильства під час «полювання на відьом», внаслідок якого в Європі протягом XV-XVIII століть було спалено та повішено більш ніж 50 тисяч осіб. Це є прикладом того, як люди, сприймаючи дії інших через об'єктив міфу абсолютного зла, асимілюють реальні факти до нього. Крім того, як доводить Р. Баумайстер, ця категорія створюється стереотипами виховання, освіти і пропаганди [20].

Саме тому у сучасній християнської філософії категорія абсолютного зла втрачає свою персоніфікацію. Зло скоріше розуміється як відсутність добра. Тому воно не має власних сутнісних характеристик, подібно до того, як не має їх темрява, котра по суті $\epsilon$ лише відсутністю світла. Для того, щоб подолати темряву, треба лише додати світла. Таким світлом, що перемагає зло, є вчення Христа. Як наголошував С. К'єркегор, християнство починає сходження, вважаючи за необхідність одкровення Боже, яке наставляє людину щодо гріха, показує їй, що гріх є не в тому, що не розуміють правого, а в тому, що його не бажають зрозуміти, не бажають правого» $[10$, с. 68]. Погоджуючись 3 думкою філософа, що зневіра $\epsilon$ «прародителькою усіх гріхів» [8, с. 524], підкреслимо водночас, що філософ при цьому твердив саме про необхідність розуміння правого. Із цієї позиції достатньо суперечливою постає думка Г. І. Савонової, що релігійна людина виходить за межі емпіричного відкриття добра і зла, вона не пізнає зло, не сумнівається в прави- 
льності чи неправильності рішень Бога, а вірить поза емпіричним визначенням можливості чи неможливості, добра і зла [17, с. 115]. На нашу думку, такий підхід саме знімає відповідальність із суб’єктів за їхній вибір. I не так з тих, хто «чітко усвідомлює те, що є вірним, але не чинить правоту», скільки з тих, які «не докладають волі, щоб дізнатися ії» [17, с. 114]. А це суперечить умовиводам християнських теологів, зокрема й твердженню С. К'єркегора, що «рабство гріху - це несвідоме відношення до зла, але демонічне - це несвідоме відношення до добра» [10, с. 85]. Тому для християнина саме пізнання добра і зла в їх Свангельському розумінні $є$ сенсом не лише духовної, а й інтелектуальної роботи. Свідоме ставлення до добра і зла надає, зокрема, можливість визначити аксіологічні критерії насильства.

Констатуючи, що існує певна відносність цінностей добра i зла та динаміка моральних цінностей, що зумовлює їхню плинність. Водночас треба наголосити, що в їхньому бутті присутні також абсолютність і сталість, що дає можливість сформулювати деякі принципи для моральної поведінки людини. Зіставивши категорії насильства, зла і гріха, Петро Матвєєв запропонував три принципи, які визначають морально виправдані насильницькі дії: 1) насильство спрямовано проти гріховного зла та його носіїв; 2) насильство є вимушеним засобом в даній ситуації; 3) конкретні насильницькі дії не порушують принципу максиміна $[13$, с. 9]. Але складність полягає у тому, що оцінка вимушеності та співмірності відповідних дій може бути доволі суб'єктивною. Не подає П. Є. Матвєєв і критеріїв визначення гріховності конкретних насильницьких вчинків. Спираючись на прийняті у християнській філософській традиції аргументи, які були викладені вище, ми пропонуємо використовувати такі три критерії, котрі можуть служити підставою для оцінювання насильницьких дій як негріховних: 1) насильство має характер попередження або протидії, а не помсти; 2) насильство не принижує гідність людини; 3) насильство скероване вищими постулатами любові, а не боротьбою за матеріальні цінності або соціально-політичні чи релігійні ідеали як такі.

Важливо наголосити, що визнаючи моральну припустимість негріховного насильства, не можна при цьому знімати всяку моральну відповідальність за те, що відбувається насильство. Вирішу168

H.Skovoroda Institute of Philosophy of the NAS of Ukraine 
ючи конфлікти насильством, суб'єкт завжди має усвідомлювати, що творить зло, хоча і допустиме, і що за це він несе відповідальність за Божим законом. Такою є драматична суперечливість буття. Тому християнська онтолого-аксіологічна парадигма, визнаючи у певних випадках припустимість насильства для боротьби з конкретними проявами гріховного зла, проголошує ненасильство як моральний обов'язок, що випливає з Свангельських заповідей. Це положення постає як духовний принцип сучасного правового суспільства, який, втім, може і не усвідомлюватися окремими соціальними суб'єктами.

Християнська онтологія насильства грунтується на біблійних настановах, відповідно до яких насильство об'єктивно $є$ породженням абсолютного зла, втім його безпосередньою суб' єктивною першопричиною постає гріх, який є наслідком спотвореного, але вільного вибору людини між двома сутностями буття - добром і злом. Проте суперечливість настанов Старого заповіту полягає у тому, що насильство розглядається у ньому також як необхідна умова покарання за скоєний гріх, і це виправдовує сумнозвісний принцип таліону. Християнство діалектично трансформує ці біблійні постулати та розриває замкнене коло насильства, трактуючи добро як любов, милосердя і прощення, даровані людству Спасителем. При цьому гріх вважається хворобою душі, яка спричинена зневірою у євангельські заповіді. На цьому твердженні грунтується християнська онтологія насильства. Відповідно до неї психологічні девіації та соціальні умови виступають лише супутніми чинниками, котрі можуть впливати на форми, в яких проявляється насильство, але не визначають його справжніх духовних мотивів. А згідно з християнською аксіологією саме оцінювання цих мотивів тільки і дає можливість зважити дії індивідуума, які він вчиняє завдяки власному вибору, на вагах добра і зла для того, щоб встановити міру його персональної відповідальності. При цьому слід звернути увагу на те, що хоча на перший погляд будь-яке насильство має оцінюватись негативно, бо воно нібито свідчить про відсутність милосердя і прощення, але більш глибоке філософське проникнення у сутність Христових заповідей дає нам можливість у межах сучасної християнської онтолого-аксіологічної парадигми розрізнити гріховне і негріховне насильство. На нашу думку, наси- 
льство, генеза якого онтологічно пов'язана зі злом, утім, може бути визначене як негріховне та мати певне виправдання 3 позицій християнської аксіології якщо воно: по-перше, має характер попередження або протидії, а не помсти; по-друге, не принижує гідність людини; по-третє і головне, скероване найвищими постулатами любові, а не боротьбою за матеріальні цінності або соціальнополітичні чи релігійні ідеали як такі. Запропоновані критерії допомагають сформувати моральне та правове судження щодо конкретних проявів насильства, але вони не дають можливості остаточно розв'язати проблему суб'єктивізму при визначенні їхніх мотивів та оцінюванні. Ця проблема і буде предметом подальших розвідок у даному напрямку.

\section{ЛIТЕРАТУРА}

1. Артемьева О. В. Непротивление злу - заповедь и ее практические смыслы. Культурное наследие, традищи и инноващии. 2016. № 1 (31). С. 83-95.

2. Бандити в Україні стали більш цинічними. Сьогодні. 2018. 15 лип. URL: https://ukr.segodnya.ua/ukraine/bandity-v-ukraine-stalicinichnee-1153685.html (дата звернення: 12.04.2019)

3. Война на Донбассе: в ООН озвучили количество погибших с начала конфликта. 24 канал. 2019. 21 янв. URL: https://24tv.ua/ru/ukraina_tag1119 (дата звернення: 12.04.2019)

4. Григорий Богослов. Слово 14. О любви к бедным. Слова. URL: https://azbyka.ru/otechnik/Grigorij_Bogoslov/slovo/14 (дата обращения: 15.04.2019)

5. Гусейнов А. А. Террористические акты 11 сентября и идеал ненасилия. Насилие и ненасилие: философия, политика, этика / ред. Р. Г. Апресяна. Москва: Фонд независимого радиовещания, 2003. $192 \mathrm{c}$.

6. Достоевский Ф. М. Дневник писателя: в 2 т. Москва: Книжный Клуб, 2011. Т. 1 [1873 и 1876 гг.]. 800 с.

7. Ильин И. А. О сопротивлении злу силою. Собр. соч.: в 10 т. Москва : Русская книга, 1995. Т. 5. 534 с.

8. Кьеркегор С. Или - или. Фрагмент из жизни / пер. с дат. С. Исаев, Н. Исаева. Москва : Академический проект, 2016. 776 с.

9. Кьеркегор С. Понятие страха / пер. с дат. С. Исаев, Н. Исаева. Москва : Академический проект, 2016. 217 с. 
10. Кьеркегор С. Страх и трепет / пер. с дат. С. Исаев, Н. Исаева. Москва : Академический проект, 2016. 154 с.

11. Лаут Р. Философия Достоевского в систематическом изложении / пер. с нем. И. С. Андреева. Москва : Республика, 1996. 447 с. $720 \mathrm{c}$.

12. Макаренко А. С. Педагогическая поэма. Москва : ИТРК, 2003.

13. Матвеев П. Е. Насилие как зло и грех. Владимир : Наука, 2002. 10 c. URL: http://matvei5.narod.ru/Ethics/ViolenceEvil.pdf (дата обращения: 18.04.2019)

14. Миссия Православной Церкви в современном мире. Шамбези. 2016. 28 янв. URL: http://www.patriarchia.ru/db/print/4360988.html (дата обращения: 18.04.2019)

15. Насилие и его влияние на здоровье. Доклад ВО3 о ситуации в мире / под ред. В. Этьенна, Г. Круга и др., пер. с англ. А. Мартынов. Москва : Весь Мир, 2003. 376 с.

16. Основи соціальної концепції Руської Православної Церкви. Київ : Інформаційно-видавничий центр Української Православної Церкви, 2002. URL: http://www.patriarchia.ru/ua/db/text/1207692.html (дата звернення: 12.04.2019)

17. Савонова Г. І. Онтологія добра і зла та проблема свободи вибору християнином у філософських міркуваннях С. К'єркегора. Грані. 2019. T. 22. № 1. C. 110-116.

18. Щороку в Україні від домашнього насильства гинуть 600 жінок. УНIAH. 2017. 09 лист. URL: https://www.unian.ua/society/2233774schoroku-v-ukrajini-vid-domashnogo-nasilstva-ginut-600-jinokinfografika.html (дата звернення: 12.04.2019)

19. Baumeister R. F. Human Evil: The Mythical and the True Causes of Violence (Paperback). Florida State University, 2015. 18 p.

20. Baumeister R. F. Human evil: The myth of pure evil and the true causes of violence Herzliya series on personality and social psychology. The social psychology of morality: Exploring the causes of good and evil / eds. by M. Mikulincer \& P. R. Shaver. Washington : American Psychological Association, 2012. P. 367-380.

21. Baumeister R. F. The cultural animal: Human nature, meaning, and social life. New York : Oxford University Press, 2005. 464 p.

22. Gibson L., Matthews Sh. Violence in the New Testament. New York: Continuum International Publishing Group, 2005. 168 p.

23. Rynne T. J. Gandhi and Jesus: The Saving Power of Nonviolence. London : Orbis Books. 240 p.

24. Zizek S. Violence. New York : Picador, 2008. 264 p. 


\section{REFERENCES}

Artemyeva, O. V. (2016). Nonresistance to evil is a commandment and its practical meanings. Cultural heritage, traditions and innovations, 1 (31), 8395. [In Russian].

Bandits in Ukraine became more cynical (2018). Syogodni. Retrieved from https://ukr.segodnya.ua/ukraine/bandity-v-ukraine-stali-cinichnee1153685.html [In Ukranian].

The war in the Donbass: the UN voiced the number of dead since the beginning of the conflict (2019). 24 kanal. Retrieved from https://24tv.ua/ru/ukraina_tag1119 [In Russian].

Grigorij Bogoslov. Word 14. About a love for poor. The words. Retrieved from https://azbyka.ru/otechnik/Grigorij Bogoslov/slovo/14 [In Russian].

Guseinov, A. A. (2003). The terrorist attacks of September 11 and the ideal of non-violence. In Apresian, R. G. (Ed.) Violence and non-violence: philosophy, politics, ethics (23-36). Moscow: Independent Broadcasting Foundation [In Russian].

Dostoevskij, F. M. (2011). Writer's diary: in 2 Vols. Moscow: Book club. Vol. 1 [1873 and 1876]. [In Russian].

Ilyin, I. A. (1995). About resistance to evil by force. Collected Works: in 10 Vols. Moscow: Russian book. Vol. 5 [In Russian].

Kierkegaard, S. (2016). Either/Or: A Fragment of Life. Trasl. from danish by S. Isaev, N. Isaeva. Moscow: Akademic project. [In Russian].

Kierkegaard, S. (2016). The Concept of Anxiety. Trasl. from danish by S. Isaev, N. Isaeva. Moscow: Akademic project. [In Russian].

Kierkegaard, S. (2016). Fear and Trembling. Isaev, S. \& Isaeva, N. (Trasl.). Moscow: Akademic project. [In Russian].

Laut, R. (1996). The philosophy of Dostoevsky in a systematic presentation. Andreyeva, I. S. (Trasl.) Moscow: Republic. [In Russian].

Makarenko, A. S. (2003). Pedagogical poem. Moscow: ITRK. [In Russian].

Matveyev, P. E. (2002). A violence as an evil and a sin. Vladimir: Nauka. Retrieved from URL: http://matvei5.narod.ru/Ethics/ViolenceEvil.pdf [In Russian]. 
Orthodox Church's mission in the modern world. (2016). VI World Orthodox Meeting, Shambezy, 26-28 january. Retrieved from http://www.patriarchia.ru/db/print/4360988.html [In Russian].

A violence and its influence on a health. In Etenna, V. \& Krug, G. (Eds.) WHO report on the situation in the world. (2003). Martynov, A. (Transl.). Moscow: Wourld. [In Russian].

The fundamentals of the Russian Orthodox Church's social concept. (2002). Kyiv: Information and Publishing Center of the Ukrainian Orthodox Church. Retrieved from http://www.patriarchia.ru/ua/db/text/1207692.html [In Ukranian].

Savonova, G. I. (2019). The ontology of good and evil and the problem of freedom of choice christian philosophical reasoning of S. Kierkegaard. Grani. 22 (1), 110-116. [In Ukranian].

600 women die from domestic violence in the Ukraine every year. (2017). UNIAN. Retrieved from https://www.unian.ua/society/2233774-schoroku-vukrajini-vid-domashnogo-nasilstva-ginut-600-jinok-infografika.html [In Ukranian].

Baumeister, R. F. (2015). Human Evil: The Mythical and the True Causes of Violence. Florida State University.

Baumeister, R. F. (2012). Human evil: The myth of pure evil and the true causes of violence. In Mikulincer, M. \& Shaver, P. R. (Eds.) Herzliya series on personality and social psychology. The social psychology of morality: Exploring the causes of good and evil (367-380). Washington: American Psychological Association.

Baumeister, R. F. (2005). The cultural animal: Human nature, meaning, and social life. New York: Oxford University Press.

Gibson, L. \& Matthews, Sh. (2005). Violence in the New Testament. New York: Continuum International Publishing Group.

Rynne, T. J. (2008). Gandhi and Jesus: The Saving Power of Nonviolence. London: Orbis Books.

Zizek, S. (2008). Violence. New York: Picador. 


\section{Mykola Nesprava}

Doctor of Philosophical Sciences, Associate Professor of the Department of International Relations and Tourism; Dnipro, Ukraine; e-mail: n.nesprava@gmail.com; ORCID: https://orcid.org/0000-0003-0415-1837

\section{The problem of violence in the Christian ontological and acsyological para- digm of good and evil}

\section{Abstract}

The aim of the article is to show the ontological sources of violence and to characterize the axiological criteria for assessing real violent actions as they are interpreted within the framework of the Christian paradigm of good and evil. Paper reveals the defining features and existential causes of violence. The author demonstrates the logical construction of the biblical ontological and axiological paradigm of good and evil, based on the analysis of the fundamental Biblical postulates. First, this paradigm interprets good as a freedom that is limited only by God's commandments. Consequently, it considers the dialectical manifestation of two factors - God's law and human freedom as an ontological prerequisite for the emergence of the problem of good and evil. In a consistent way, this paradigm determines that sin is the abuse of freedom that manifests itself in violating of God's commandments, and that is conscious human's choice in favor of evil. It states that the fall from grace was the root cause of violence, and the existence of violence in the modern world is caused by despondence. Thus, the author reveals key positions of the relationship between evil, sin and violence based on the logic of the considered biblical paradigm. At the same time he discovers the difference in the interpretation and evaluation of violence contained in the Bible. The author shows that in the Old Testament violence is viewed not only as evil, but also as a necessary punishment for sin or just vengeance. On the contrary, the Christian ontological and axiological paradigm, recognizing the permissibility of violence to deal with the concrete manifestations of sinful evil in certain cases, proclaims nonviolence as a moral obligation arising from Gospel commandments. For Christians good means love, charity and forgiveness. From this position, the author compares the concept of non-resistance to evil with violence and the concept of the validity of force resistance. The article reveals the significance of Christian philosophers' inference that only victory over evil in one's soul opens the possibility for a person to use force equally. The examples given in the paper show that the problem of violence becomes particularly complex due to the subjectivity of the assessment of good and evil as social phenomena. Relying on the po- 
sition of the Christian ontological and axiological paradigm, the author argues that there is an essential differentiation between sinful and non-sinful violence. He offers the criteria by which violent actions should be classification as nonsinful. The article proves that violence, the genesis of which is ontologically linked to evil, can, however, be defined as non-sinful and have some justification from the standpoint of Christian axiology if: firstly, it has a character of warning or counteraction, and not revenge; secondly, it does not degrade the human dignity; thirdly, and most importantly, it is directed by the higher postulates of love, rather than by the struggle for material values, socio-political or religious ideals.

Keywords: God's commandments, faith, freedom, sin, spiritual values, love, charity, non-resistance, force, moral evaluation, responsibility. 